Meta

Journal des traducteurs

Translators' Journal

\title{
Translating Rimbaud's "Illuminations": Games with Words
}

\section{Daniel Slote}

Volume 23, numéro 1, mars 1978

La traduction poétique

URI : https://id.erudit.org/iderudit/004189ar

DOI : https://doi.org/10.7202/004189ar

Aller au sommaire du numéro

Éditeur(s)

Les Presses de l'Université de Montréal

ISSN

0026-0452 (imprimé)

1492-1421 (numérique)

Découvrir la revue

Citer cet article

Slote, D. (1978). Translating Rimbaud's "Illuminations": Games with Words.

Meta, 23(1), 86-96. https://doi.org/10.7202/004189ar d'utilisation que vous pouvez consulter en ligne.

https://apropos.erudit.org/fr/usagers/politique-dutilisation/ 


\section{Translating Rimbaud's "lluminations": Games with words}

One of the most interesting challenges in translation is the rendering of plays on words. Sometimes there is no insuperable obstacle (the word play in Alice in Wonderland for instance is difficult but possible to translate); at other times the difficulties are so complex as to defy a satisfactory solution. The problems in Rimbaud's Illuminations are an excellent example : this series of prose-poems, in its entirety, is one vast word-game; the poems, taken individually, are a network of word-games which in turn link up subtly, at times obviously, to the master word-game : the series itself.

Theseus had only one thread to follow; here, in any given Illumination, we have many threads all leading somewhere. To the heart of the labyrinth ? Many lead into apparent dead ends, or double back upon themselves; others lead right out of the poem to become inextricably tangled in the series as a whole.

Should the translator make himself aware of these threads or should he ignore them and hope for the best? If the translator follows the second course he will end up with a skeleton on his hands : a structure without the "flesh" of the original. The life of the original, in the Illuminations, is directly dependent for its blood upon an elaborate pattern of word-games. Without grasping some of them, on some of their levels, the reader will find the poems « mean » little in French; an English translation, under these conditions, will merely reflect the bones.

The translator of technical texts must research his subject : he must document himself thoroughly before attempting even a sketchy version of the original. The same, I dare say, holds true for literary translation in general, and for the translation of poetry in particular, if and when of course the poetry is dense enough to make the cultivated reader think at all about its ramifications.

I do not intend to put forth the preceding remarks as a form of prolepsis. I feel that any translation approach which ignores the word-game structure of the Illuminations cannot succeed no matter how valid other aspects of that approach may be. A structuralist approach, as outlined elsewhere in this special issue of Meta, is certainly edifying but would not be complete in this particular case. 
Here is Dévotion from the Illuminations and my translation of the poem : DEVoTION

DEVOTION

A ma sour Louise Vanaen de Voringhem : - sa cornette bleue toulince à la mer du Nord. - Pour les naufragés.

À ma sceur Léonie Aubois d'Ashby. Baou! - l'herbe d'été bourdonnante et puante. - Pour la fièvre des mères et des enfants.

À Lulu, - démon - qui a conservé un goût pour les oratoires du temps des Amies et de son éducation incomplète. Pour les hommes. - À madame...

À l'adolescent que je fus. À ce saint vieillard, ermitage ou mission.

A l'esprit des pauvres. Et à un très haut clergé.

Aussi bien à tout culte en telle place de culte mémoriale et parmi tels événements qu'il faille se rendre, suivant les aspirations du moment ou bien notre propre vice sérieux.

Ce soir, à Circeto des hautes glaces, grasse comme le poisson, et enluminée comme les dix mois de la nuit rouge - (son cœur ambre et spunk), - pour ma seule prière muette comme ces régions de nuit et précédant des bravoures plus violentes que ce chaos polaire.

A tout prix et avec tous les airs, même dans des voyages métaphysiques. - Mais plus alors.
To my sister Louise Vanaen de Voringhem : - Her blue coif pointed toward the North Sea. - For the castaways.

To my sister Leslic Aubois d'Ashby. 'Andsome! - the summer grass droning and reeking. - For the fever of mothers and children.

To Lyla, - demon - who still has a taste for the chapels of the Amies period and her incomplete education. For men! - To milady...

To the adolescent $\mathbf{I}$ was. To that saintly old man, hermitage or mission.

To the spirit of the poor. And to a very high clergy.

And also to whatever cult in such place of memorial cult and amid such events that one must go there, acting on the aspirations of the moment or else on our own serious vice.

That evening, at Circeto of the cold glass, slimy as a fish, and illuminated like the ten months of the red night, - (his amber and spunk heart), - for my only prayer, silent like these regions of the night and just before bravery more violent than this polar chaos.

At all cost and with every air, even in metaphysical voyages. But that time is over.

The very title is a play on words. I presume that Rimbaud is using the French word here instead of the English. There is an acute accent (é) in most editions, but one must remember there is no known manuscript of this poem, and that Rimbaud had a penchant, in the Illuminations, for giving curious English titles to several of the poems in the series (Fairy; Bottom; Being Beauteous). The poem is a parody of a prayer. At least three levels are intended here : 
dévotion - culte particulier que l'on rend à un saint.

dévotion - à une église, à un lieu de pèlerinage.

dévotion - attachement, dévouement, «une véritable dévotion pour sa fiancée ». Etre à la dévotion de quelqu'un (lui être tout dévoué). Robert, page 203.

One translation problem that arises immediately : is it « devotion 》 or \& devotions $\gg$ in English ? I opted for the singular because I felt the plural might have tilted the scales too far in the religious direction. After all, the secular, even blasphemous tone of this poem is uppermost. Religion is an obsessive theme in the works of Rimbaud : "Les Sours de Charité 》; "Premières Communions »; "Un cour sous une soutane»; and many others. Here, he uses the scaffolding of religion in constructing his «prayer», but the gods to whom the prayer is addressed are very human ones.

À ma sœur (1) Louise (2) Vanaen de Voringhem : - (3)

To my sister (1) Louise (2) Vanaen de Voringhem : - (3)

(1) Another play on words on at least two levels, religious and secular. The secular play involves the use of «søur» in French gay terminology. The English «sister» is a poor equivalent; the religious level is preserved of course, and although «sister» can apparently be used jokingly between male homosexuals it is not as current as the French "sœur 》 in the same context (cf. Genet : Notre-Dame des Fleurs; Miracle de la Rose; Querelle de Brest).

(2) The ambiguity of «Louise » involves a feminized masculine name, « Louis». The ambiguity is preserved in English.

(3) The Flemish (or pseudo-Flemish) tone here is the probable echo of a friend's name, Vermersch, who spent some time in England with Rimbaud.

Sa cornette bleue tournée à (4) la mer du Nord. (5)

Her blue coif pointed toward (4) the North Sea. (5)

(4) The mock-religious tone here is strong; there is a play on the word «cornette » which is not found in the English translation. The uppermost idea, « coif », does not convey the following : «cornette», a) femme dont le mari est infidèle : b) long pavillon à deux pointes; (Robert, page 960). Pity, since the whole poem (and others, especially the Saison en Enfer) deals mockingly with the theme of infidelity, among others. The other notion of "pavillon $\gg$ is important because of the echoes therein linking this Illumination to several others : Démocratie ( le drapeau va au paysage immonde... »); Génie («les drapeaux d'extase »); and especially Barbare ( le pavillon en viande saignante sur la soie des mers et des fleurs arctiques... »). The colour « blue» is a link to Bottom ( je me trouvai néanmoins chez ma dame, en gros oiseau gris-bleu... ») ; to Métropolitain ( Du détroit d'indigo... »); to Mystique ( «... l'abîme fleurant et bleu là-dessous ».) ; and in particular to Fleurs which mentions the "god» or the «being 》 present in several key Illuminations : "Tel qu'un dieu aux énormes yeux bleus et aux formes de neige... » It is obvious that translating «bleue » (4) by «blue » is no exploit; I mention the significance of the adjective because it helps the 
translator to follow the threads through the poems and because it constitutes part of the «documentation 》 for the subject at hand. The translation \& pointed toward " does evoke " points 》 at least, perhaps even « horns »; it is certainly a stronger verb than the French one, with vaguely aggressive or erotic overtones. A compensation for the loss between "cornette » and "coif».

(5) The theme of water, of the sea is pervasive in the Illuminations. No problem here : the North Sea, associated with Rimbaud's visits to the British Isles is important in this poem because it evokes various aspects of Rimbaud's experiences there. It is also a link to several Illuminations, one of which is found in Métropolitain . " ... aux mers d'Ossian. »

Pour les naufragés. (6)

For the castaways. (6)

(6) No problem here : the «castaways 》 are Rimbaud and his friends on the inclement shores of England. A «slippage» however is to be noted between 《nau- (« naufragés 》) where « eau » is evoked and the English which suggests water remotely in the last syllable «ways» of «castaways ».

A ma sœur (7) Léonie Aubois d'Ashby. (8)

'To my sister (7) Leslie Aubois d'Ashby. (8)

(7) See note (1).

(8) The male/female Léon/Léonie ambiguity is fairly well rendered in English by «Leslie» which can be either a man's or a woman's name.

Baou! (9)

'Andsome ! (9)

(9) Important word. A phonetic transcription by Rimbaud of «beau » spoken by an English «uncultivated》 person, perhaps a Cockney. The diphthong is eloquent. Since this adjective, in the masculine, refers to "soeur », the equivocal nature of the whole poem is emphasized. The English "'Andsome " reflects the pronunciation of the original (dropping the $\langle h »$ in $《$ handsome $\gg$ ) ; it keeps the ambiguity by the fact that «handsome » usually applies to a man. One last remark here : given the poet's penchant for word games, «baou» may even be an echo of the way in which the last syllable of Rimbaud's own name was pronounced by his English friends.

l'herbe d'été (10) bourdonnante et puante. (11)

The summer grass (10) droning and reeking. (11)

(10) Summer was Rimbaud's great season. Many references suggest that it was associated with erotic ardour : Aube; Enfance; Bottom; and of course the Saison en Enfer, the major part of which was written in July and August of 1873.

(11) The two French verbs here are dear to Rimbaud if his frequent use of them can be taken as an indication. The English translations \& drone» and "reek» are strong and quite effective in their own way. "Drone», other than the paronomastic links with the French "bourdonner» also refers to the male 
bee, attendant upon the queens. I purposely weighted the verb with a different denotation, in this case to reinforce the equivocal aspect of the poem in English, not always well rendered elsewhere.

Pour la fièvre (12) des mères (13) et des enfants. (14)

For the fever (12) of mothers (13) and children. (14)

(12 to 14$)$ «Fièvre» is an important word, rendered in English by «fever» to give as much latitude as possible to what Rimbaud intends here : ardour, «délire», passion, rage, etc. Rimbaud's mother, called «la bouche d'ombre» (among other epithets given to her by her son), was a fiery, violent-tempered and autocratic disciplinarian who was not amused by her son's wanderings, nor his friendship with Verlaine and others in Paris. «Mère» and «sœur 》 often fuse in an ambiguous context (see «Délires I » of the Saison en Enfer 》).

$$
\begin{aligned}
& \text { A Lulu (15) - démon - (16) } \\
& \text { To Lyla (15) - demon - (16) }
\end{aligned}
$$

(15) One of Rimbaud's epithets (slightly altered) for Verlaine; the English name plays on «lie» in all its acceptions as well as suggesting a man's name and a woman's.

(16) Important word in Rimbaud's universe. We find it in the Saison en Enfer in an equivocal context : "c'est un Démon, vous savez, ce n'est pas un homme » (Verlaine speaking of Rimbaud, 1' «époux infernal»); and in Vagabonds of the Illuminations we find this reference to Verlaine : «ce satanique docteur ».

qui a conservé un goût pour les oratoires (17)

who still has a taste for the chapels (17)

du temps des Amies et de son éducation incomplète. (18)

of the Amies period and her incomplete education. (18)

(17-18) Difficult to transpose. The context tells us that all of this is not « nice 》; that « oratoires » is close to «Oratoriens 》, those «mauvais catholiques 》 Verlaine learned to despise after his conversion, perhaps because they were secular priests living in common but not bound by any monastic vow ; that « oratoires 》 is linked to «dévotion» and therefore to the title; that «oratoires» are «petites chapelles 》 (cf. Genet) ; that « oratoires » are « lieux destinés au culte » (Robert, page 763), etc. How to get all this information across? The English "chapels " has the mock-religious overtones but most of the other harmonics are lost. The «Amies suggest the persons mentioned at the beginning of the poem; there is an echo of Verlaine's poems in Femmes and perhaps of his Hombres. It is the last allusion (18) however which is conclusive : Rimbaud is undoubtedly speaking of Verlaine. The poem Vagabonds contains a clear indication of what Rimbaud means here by Verlaine's «éducation incomplète ». He speaks of his commitment to Verlaine : "le rendre à son état primitif de fils de soleil ». There are others, especially in the Saison en Enfer; suffice it to say that the ambiguity is superbly created in French (the masculine "démon 》; the feminine «Amies $»$ ). This is rendered in English fairly well by a mixture of genders ( Lyla»; «demon»; «her incomplete education») 


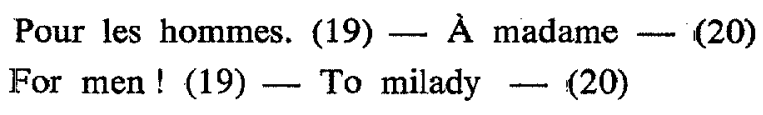

(19-20) The clincher. The masculine/feminine play has come to an end. The exclamation mark seemed necessary in English to heighten the comic effect. The mysterious «madame the Illuminations : Bottom; Après le Déluge, and most probably elsewhere in other guises. One notes as well that the form of the "prayer» is broken here : « $A$ naadame - - is added after the «Pour» clause which ends the first two «prayers». The « $\grave{A}$ madame» formula suggests strongly that it harks back to the first segment of the paragraph. «À Lulu».

À l'adolescent que je fus. (21)

To the adolescent $I$ was. (21)

(21) The adolescence/senescence theme is important; again, it is part of the woof/warp holding the tapestry of the Illuminations together. No problem in the English translation; the «que » is not rendered, but * the 》 makes the English line about as weighted as the original in which the $" l^{\prime} \gg$ has little density : schernatically then, « 1 '» (light) $=$ 《the » (heavy) ; « que» (heavy) = $\mathrm{O}$ (light). This is but one example among many in the translation where the weight (or "value ») of a word or words in the original is accounted for in English. The illusion of rhythm approximation is sometimes achievable in this way.

À ce saint vieillard, (22) ermitage ou mission. (23)

To that saintly old man, (22) hermitage or mission. (23)

(22) This theme is the counterpoint to adolescence. It runs through Phrases; is perhaps referred to in the person of the "brahmane» in Vies; is probably present in the fourth section of Enfance : « je suis le saint...»; « je suis le savant... $\gg$ What is annoying to me in my translation is the slippage in the ambiguous \& ce $»$ : the definite article is not appropriate here as a translation of the French demonstrative ; one must decide between «this 》 and «that 》, which constitutes a slippage in terms of time (an old man from the past or an old man to come?), and in terms of space (an old man nearby or far away?).

(23) Two words which Rimbaud associates with peace, beauty and the good summed up in Génie. The English is as indefinite as the French, this time by strictly reflecting the order; luckily the different meanings of «mission 》 are detectable in both languages; the break in thought between (22) and (23) is preserved by not yielding to the temptation to expand (23) in any way.

À l'esprit des pauvres. (24) Et à un très haut clergé. (25)

To the spirit of the poor. (24) And to a very high clergy. (25)

(24-25) Much could be said about Rimbaud's ambivalent attitude towards religion. It is a complex question which does not concern us here. The English translations (24) and (25) are purposely literal; no expansion at all. "Spirit " in (24) is as ambiguous here as the French "esprit " or better still, as polysemous. 
Aussi bien à tout culte (26), en telle place de culte (27) mémoriale et parmi teis événements qu'il faille se rendre, (28) suivant les aspirations (29) du moment ou bien notre propre vice sérieux. (30)

And also to whatever cult (26) in such place of memorial cult (27) and amid such events that one must go there, (28) acting on the aspirations (29) of the moment, or else on our own serious vice. (30)

(26 to 30) I think it advisable to see this paragraph in its entirety before breaking it up for analytic purposes since the syntax is complex. Many ideas, puns, allusions, clamour for attention and the translator is in trouble. The English sticks close to the original in many instances, which is often the best escape hatch when the images, as here, bend back upon themselves and lead out of the poem into a diffuseness which defies analysis and "ultimate meaning 》 (Verlaine's remark about these poems comes to mind : "délicieusement faux exprès »). The translation attempts, with the word «cult » (26 and 27) to render the French «culte» where, on the calembour level, a part of the human anatomy is evident; the English rendering suggests «cull» and therefore «pick up »: an erotic calembour more subtle than the original but not by choice, unfortunately. In (28) we have a perilous transposition : the English is concrete, taking «place» literally, although the French «se rendre 》 may mean «surrender » in every sense of the word. The explanation for the English rendering is this : "place " is concrete ; "go there " is concrete; "se rendre " on the other hand is much more figurative ; «acting on 》 duplicates this figurative aspect (or abstract dimension) while the French «suivant 》 can be both concrete and abstract. There is then a balancing act in the translation between these tendencies which is weaker than the original but which does convey some of the blurred allusions of the French.

In (29) we have another difficult word to capture in all its guises : « aspirer» has several polysemous facets in French (cf. Verlaine's poem "Aspiration »); « to aspire » is difficult to twist into ambivalence, except in phonological terms : the first syllable is an anatomical echo of the French «culte».

The presence of the word «vice» (30) is one of the major reasons for giving an erotic cast to this part of the poem in particular and to the whole poem in general.

Ce soir, (31) à Circeto des hautes glaces, (32) grasse comme le poisson, (33) et enluminée comme les dix mois de la nuit rouge - (34) (son cour ambre et spunk), (35) - pour ma seule prière muette comme ces régions de nuit (36) et précédant des bravoures plus violentes (37) que ce chaos polaire. (38)

That evening, (31) at Circeto of the cold glass, (32) slimy as a fish, (33) and illuminated like the ten months of the red night, - (34) (his amber and spunk heart), (35) - for my only prayer, silent like these regions of the night (36) and just before bravery more violent (37) than this polar chaos. 
(31 to 38) Antoine Adam once noted Verlaine's \& postulations contraires vers l'idéal et vers l'ordure ». The same remark might well apply to Rimbaud's major works in general ; Dévotion is a good example of this dichotomy in the poet. The paragraph ( 31 to 38$)$ is hermetic; the blend of very intimate memories with the dominant lietmotif through the Illuminations of « polar chaos» is typical of Rimbaud at his most enigmatic. And for the translator, at his most difficult. There is no «message » to work with, no concept to transpose carefully and faithfully; there is only the purposely blurred vision before us, and the blur is the message. Various wisps are in focus ; these can be analyzed and transposed; the rest can only be coped with by means of close adhesion to the original, in the hope that the order of the words and, where possible, the echo of their sounds, will produce a similar blurred effect on the English reader. But is it the same blur as in French? And even though it is a blur, how much mist is no longer a blur but a dense fog, opaque and impenetrable?

In (31) the same problem as in (22) arises. Is it "this 》 or «that 》 or even «the »? The whole poem seems to be another of those «adieux» Rimbaud was fond of : the last part of the Saison en Enfer; in the Illuminations themselves there is Dévotion and of course Solde. For this reason, and because of the tense in « je fus » (21) as well as the past tense in the last line of this poem, I have opted for "that» which refers to something past - but the slippage is apparent.

(32) A major key to the enigma. "Circeto» is constructed from «Circe», and the Latin word «cetus ». Circe, of course, was the enchantress of Greek mythology ; one of her achievements was to change Ulysses' men into swine. In the Saison en Enfer ( Délires II, Alchimie du verbe »), Rimbaud tells us "Ainsi j'ai aimé un porc». The Latin «cetus» originally applied to any big sea creature, but later referred to big sea mammals, and in particular to the whale. The word conjures up many of the images that follow in this paragraph : " hautes glaces », " grasse », " poisson », « nuit rouge » (of the pole), « ambre » (ambergris, from the sperm whale), «spunk (British slang - at one time for seminal fluid), « régions de nuit » (of the pole), and finally «chaos polaire» where the insistance on «pole» and its erotic connotations becomes almost too evident. The last series (pole and polar) links up in the translation with "coif pointed toward the North Sea (4 and 5).

The next important aspect of this segment is the changes Rimbaud effects once again in the linguistic pattern of his « prayers (see note 20). Heretofore the pattern was generally : À... + personne ou chose... + incise + pour + ceux à qui la prière doit «profiter»: À ma sœur... sa cornette bleue..., pour les naufragés. In (32) as well as in the preceding paragraph the pattern shifts to finally break down almost completely in this paragraph and the last one. I have opted for the locative («at Circeto 》) in the translation; the reasoning goes back to (27) where a place was mentioned. The ending of «Circeto» was another clue : it strongly suggests a place name or district as in «Soho»; there are examples in the Illuminations themselves : Promontoire for instance refers to «Scarbro 》 which the editors of the Pléiade Edition of Rimbaud's works (de Renéville and 
Mouquet) felt compelled to «correct» thus : «Scarborough», nicely missing the phonetic point completely. One should note as well, to buttress the "place theory » that «Voringhem » and «Ashby suggest place names. It is true that the use of «at 》 rather than «to » destroys the linguistic pattern used in earlier segments but $I$ feel it is justified if my theory about Circeto being a fictitious place name is correct. Finally, «cold glass » is fairly successful in that it suggests a looking glass as well as ice (or icebergs) ; the French "glace» is preserved practically intact on the phonological level.

(33) The feminine singular here is perturbing. Within the paragraph it can refer to the following : «Circeto»- one remembers that «Carthage » was feminine in Latin; «prière »; the person to whom the «cour» belongs in «son cour ambre et spunk »; perhaps ultimately to «mer», implicit in the segment. The English rendering, skirting this ambiguity in the syntax, follows the French order closely with more or less the same blurred result as in the original.

The word «slimy 》 is a semantic link to «spunk» (35) as indicated earlier. The image in French is unpleasant and this resonance has been carried over into English.

(34) Interesting segment because of «enluminée » which suggests the title of the series; the English translation does as well, since «illuminated» can of course apply to a manuscript or text.

The colour red runs through the Illuminations and is another image-link : Barbare, Bottom, H, Fête d'hiver, Métropolitain, etc.

(35) A perilous segment for several reasons. The French ambiguity of «son» is lost in translation; a choice of gender was necessary, dictated in this instance by what appears to be a central theme of this Illumination (as seen in the first three paragraphs in particular). So the heart, in translation, belongs to a man. Then we come to «ambre»: the word means not only «amber» but «ambergris » as well. A play on words therefore that links up with "grasse » and later with «spunk». The other threads are just as intricate : the colour red for night and the reference to a heart; the «fish» images culminating in "polar chaos».

(36 to 38 ) Not too many problems here. The French \& bravoures » might have been rendered by «exploit»I suppose («exploit» in an erotic sense is present in other Illuminations), but I thought it advisable in this instance to keep some of the French sounds in English since the erotic point has already been made. Again, the problem of «this » or «that 》 is insoluble.

À tout prix et avec tous les airs, (39) même dans des voyages métaphysiques. (40)

At all cost and with every air, (39) even in metaphysical voyages. (40)

(39) The linguistic pattern used at the beginning of the poem and repeated several times breaks down here. I rendered $\langle\bar{A}$ » by «At», a link to the « at of (32) although of a different value obviously. «Prix $»$ and « cost» 
correspond nicely and prepare us for Solde (Remnant Sale); the plural notion of «tous les airs » is kept in English.

(40) The whole poem of course is, in a sense, a "voyage métaphysique " and is a fitting penultimate note. I think the root «méta » is not accidental in this context : the miraculously blasphemous «changes» wrought throughout the poem are neatly echoed here in their ambiguous physical aspects (men/women; men/swine; erotic «sisters $» /$ saintly old men, etc.). Even «voyage» suggests the sea again and is a link to the first paragraph of the poem. None of these elements poses any profound problem in translation.

Mais plus alors. (41)

But that time is over. (41)

(41) The most difficult problem of all and ultimately insoluble if one is to play on all the levels Rimbaud does. The segment is probably « ungrammatical » as N. Wing suggests in his Aspects of Poetic Structure in Rimbaud's "Illuminations», but who cares? Rimbaud underlined «alors», which is perhaps an indication of its language level : it may be a «tag» as in «Ah ça, alors!» Next problem : is «alors » temporal or sequential ? These polysemous teasers make the end of the poem perfectly but maddeningly open, vast, limitless. The translator must strive to capture a few levels, but here the slippage in the translation is most evident : I opted for «alors temporal, given the «past » feeling of the whole poem. Next problem : «plus». The ambiguity is perfect : if the $\ll \mathrm{s} \otimes$ is pronounced, then we have a meaning opposite to the one the word has if the $« s »$ is not pronounced. I opted for «plus» negative because of the apparent rejection, in the poem as a whole, of past experiences. Finally, I emphasized «that» to give a contemptuous ring to the segment which I detect in «alors».

I think the conclusion to all this is fairly obvious : the Illuminations, with perhaps one or two exceptions, are practically impossible to translate satisfactorily. I want to stress the fact that I do not feel this about all poetry or «poetic prose». In the past Baudelaire and Mallarmé succeeded brilliantly in their translations of Poe ; Marguerite Yourcenar and Gregory Rabassa, closer to us in time, have given us superb poetry or prose translations. But there was an ultimate meaning to grapple with in the original ; there is none in the Illuminations, or to be more accurate there are multiple meanings (see the Introduction by Robert Walton to my translation of the Illuminations). The problem of rendering plays on concepts and metaphors or simply with words is of course the lot of the literary translator. With Rimbaud, however, there is no fixed point of reference; there almost always is with other writers, even the most abstruse. An example : this exchange between Alice and the Duchess in Alice in Wonderland :

Alice : ... the earth takes twenty-four hours to turn round on its axis -

Duchess : Talking of axes, chop off her head!

The pun is not easy to transpose, but is possible as different translators of the book have shown. Let us suppose, however, that Carroll had not added « chop 
off her head $»$ (our point of reference) but «pigs often have wings, you know ». Rimbaud does something like this to many of the Illuminations; he covers over the trails, piles allusion upon allusion until the play's the thing if I may pun ; often, for the translator of Rimbaud, the play's the trap. One or two levels can be transmitted with a little luck but the others remain stubbornly there in the original, detectable but unco-operative. I suggest that a series of translations of the same poem might be a solution : Dévotion can give rise to at least ten versions, all of which, translated on different levels, could be read like some poetic palimpsest until the English reader gets the same multiple «messages » as in the original creative process. I admit the process could be laborious, perhaps even boring for a lesser writer than Rimbaud, but it might be attempted in certain cases of great poetry such as his.

We all know that Tweedledum and Tweedledee were enantiomorphs; no such curious miracle is possible with Rimbaud's works and their imperfect reflections in translation - until further notice.

Daniel SLOTE

\section{SELECTED BIBLIOGRAPHY}

ADAM, A., Verlaine, Paris, Hatier, 1953.

ARNOULT, P., Rimbaud, Paris, Albin Michel, 1943.

BACHELARD, G., l'Eau et les rêves, Paris, José Corti, 1942.

BATAILLE, G., "Le bonheur, l'érotisme et la littérature ", dans Critique, avril 1949.

BÉGUIN, A., «Découvertes rimbaldiennes », dans Empédocle, no 3, juin-juillet 1949.

BONNEFOY, Y., «La décision de Rimbaud », dans Preuves, janvier 1960.

CARRÉ, J.-M., la Vie aventureuse de Jean-Arthur Rimbaud, Paris, Plon, 1948.

CHADWICK, C., Études sur Rimbaud, Paris, Nizet, 1960.

COLÉNO, A., les Portes d'ivoire, Paris, Plon, 1948.

COULON, M., Au caur de Verlaine et de Rimbaud, Paris, Le Livre, 1925.

DELAHAYE, E., les Illuminations et Une Saison en Enfer de Rimbaud, Paris, Messein, 1927.

DHÔTEL, A., Rimbaud et la révolte moderne, Paris, Gallimard, 1952.

ETIEMBLE, R., le Mythe de Rimbaud (en plusieurs tomes), Paris, Gallimard, début en 1954.

FAURISSON, R., «A-t-on lu Rimbaud?" dans la Bibliothèque volante, Paris, 1970.

FONGARO, A., "Notes sur la genèse de "Cellulairement ", dans Revue des sciences humaines, avril-juin 1957.

FONTAINAS, A., Verlaine-Rimbaud, Paris, Librairie de France, 1931.

GARDNER, M., The Annotated Alice, Penguin, 1974.

HACKETT, C., Rimbaud l'enfant, Paris, José Corti, 1948.

IZAMBARD, G., Rimbaud tel que je l'ai connu, Paris, Mercure de France, 1946.

LACOSTE, H., "L'évolution psychologique de Rimbaud d'après son écriture », dans le Mercure de France, novembre 1936.

LAGRIFFE, L., "Les deux aspects d'Arthur Rimbaud ", dans Journal de psychologie normale et pathologique, novembre-décembre, 1910.

MARITAIN, J., Creative Intuition in Art and Poetry, New York, Noonday Press, 1955.

MICHAUD, G., Message poétique du symbolisme, Paris, Nizet, 1961.

RIMBAUD, A., Euvres complètes, Paris, Gallimard (Pléiade), 1967.

RUCHON, F., Rimbaud, documents iconographiques, Genève, Cailler-Vésanaz, 1946.

SLOTE, D., les Obsessions et délires de Rimbaud, Thèse de doctorat en Sorbonne, 1962.

SLOTE, D., Illuminations (traduction des Illuminations de Rimbaud), Montréal, Editions Maisonneuve, 1971.

STARKIE, E., Arthur Rimbaud, London, Faber and Faber, 1962.

THIBAUDET, A., " Le triptyque de la poésie moderne (Verlaine, Rimbaud, Mallarmé) » dans Causeries françaises, no 7, 15 février 1924.

THRIPPE, L., Rimbaud : The Solution, Thèse de doctorat inédite, 1975.

VERLAINe, P., les Poètes maudits, Paris, Messein, 1920. 